УДК 628.3:631.67

DOI https://doi.org/10.32848/agrar.innov.2021.5.12

\title{
ОЦІНКА ПРИДАТНОСТІ СТІЧНИХ ВОД ДЛЯ ЗРОШЕННЯ СІЛЬСЬКОГОСПОДАРСЬКИХ КУЛЬТУР
}

\author{
Скок С.В. - кандидат сільськогосподарських наук \\ https://orcid.org/0000-0003-3178-0292 \\ Херсонський державний аграрно-економічний університет
}

Постановка проблеми. Сучасний розвиток суспільства характеризується значними негативними змінами водного середовища, які спричинені безконтрольним використанням водних ресурсів у всіх сферах економіки. При цьому основним водокористувачем $є$ сільське господарство, яке витрачає $70 \%$ від усіх світових запасів води. Безповоротні втрати води під час зрошення сільськогосподарських культур сягають 60\%. Найбільш уразливою ланкою гідросфери $€$ поверхневі водотоки та водойми, які є основним джерелом водокористування.

За останні 30 років спостерігається підвищення середньорічної температури на 1,2 градуси та незмінна кількість опадів, що формують негативний водний баланс у південних регіонах України [1]. У зв'язку зі скороченням площі атмосферного зволоження на 10\% зростає нагальна потреба у постійному зрошенні та водорегулюванні. За прогнозами Міжурядової групи експертів зі зміни клімату, відбуватиметься подальше глобальне потепління у всіх регіонах планети, що сприятиме погіршенню умов природного вологозабезпечення сільськогосподарських земель.

Отже, ураховуючи глобальні зміни клімату, дефіцит водних ресурсів, зростання водокористування у сільському господарстві через збільшення площ зрошуваних земель, актуальним завданням сучасності $€$ пошук альтернативних джерел водозабезпечення за рахунок повторного використання каналізаційно-поверхневих стічних вод із застосуванням ресурсозберігаючих методів зрошення сільськогосподарських земель.

Аналіз останніх досліджень і публікацій. Світова та вітчизняна практика використання стічних вод у сільському господарстві свідчить про постійне збільшення їхньої частки у зрошенні, що сприяє підвищенню врожайності сільськогосподарських культур, поліпшенню екологічного стану річок за рахунок усунення скиду міських стоків, економії запасів прісної води. Прикладом ефрективного використання стічних вод для зрошення сільськогосподарських культур є Ізраїль, де з 500 млн $\mathrm{M}^{3}$ утворених стічних вод 90\% очищених вод використовується для зрошення овочів та кормових культур [2].

За науковими дослідженнями S.R. Salakinkop [3] використання стічних вод для зрошення земель сприяє підвищенню родючості ґрунту та збільшенню врожайності зернових культур за системою безперервного поливу. Однак тривале зрошення стічними водами сільськогосподарських культур призводить до накопичення важких металів у ґрунтах, що потребує вдосконалення технологій очистки стічних вод від стійких полютантів.

О.М. Маценко [4] наголошує, що стічні води є ефективним та стабільним джерелом енергії, цінних пожив- них речовин, органічної речовини та інших корисних побічних продуктів. Для розвитку циркуляційної економіки головним інструментом $€$ реклеймінг, що ґрунтується на повторному використанні стічних вод та корисних речовин у сільському господарстві [2].

На думку М.М. Городнього [5], для удобрення земельних угідь та підвищення родючості ґрунтів ефективним $€$ застосування осаду стічних вод, унаслідок чого утилізується 30-70\% загального їх об'єму.

Однак, незважаючи на досягнення науки та передового досвіду, питання зрошення стічними водами сільськогосподарських земель є маловивченим, тому важливим завданням $€$ здійснення комплексних досліджень під час зрошення стічними водами із застосуванням сучасних технологій їх очистки відповідно до вимог якості води за агрономічними та екологічними критеріями.

Мета статті. Здійснити оцінку придатності стічних вод для зрошення сільськогосподарських культур за агрономічними критеріями.

Матеріали та методика досліджень. Придатність каналізаційно-поверхневих стоків за агрономічними критеріями для зрошення сільськогосподарських культур установлена відповідно до ДСТУ 2730:2015 «Захист довкілля. Якість природної води для зрошення. Агрономічні критерії» [6], можливість розширення площ зрошення розраховано за методикою розрахунку ресурсозберігаючих режимів зрошення сільськогосподарських культур [7].

Оцінка придатності стічних вод для зрошення включала рівень небезпеки розвитку деструктивних процесів на зрошуваних ґрунтах за такими показниками:

- засолення ґрунтів за сумою токсичних солей;

- залуження Ґрунтів за загальною та токсичною лужністю;

- осолонцювання ґрунтів за відношенням вмісту лужних катіонів натрію і калію до суми усіх катіонів.

Придатність води для зрошення визначається за мінералізацією, кальцієвим показником, $\mathrm{pH}$, токсичною лужністю, загальним умістом хлору, хімічних сполук, коефіцієнтом іонного обміну та хвороботворних мікроорганізмів.

Результати досліджень. Основним лімітуючим фактором, який визначає ефективне ведення сільського господарства в умовах глобальних змін клімату, є зволоження. Щорічна потреба води для зрошення сільськогосподарських культур південних регіонів України становить 6 167,5 м³/га. Ураховуючи низьку водозабезпеченість місцевими водними ресурсами Херсонської області $\left(0,22\right.$ тис м $^{3}$ на одного жителя на рік), посушливий клімат, знижуються продуктивність рослинництва, 
ефрективність використання земельно-ресурсного потенціалу. Проблема вологозабезпечення земель Херсонської області посилюється зростанням ефективних температур вегетаційного періоду на 300-400 градусів, зменшенням кількості опадів у зимовий період на $17 \%$, підвищеним умістом солей, що призводять до осушення орних земель [8]. 3 урахуванням дефріциту водних ресурсів виникає нагальна необхідність використання альтернативних джерел зрошення.

Сьогодні у великих містах спостерігається незадовільний стан системи каналізування, низький рівень очистки стоків, застосування неефективних технологій утилізації осадів, зростання кількості забруднених стічних вод, які негативно впливають на навколишнє природне середовище. При цьому полютанти включаються у біогеохімічні цикли кругообігу речовин, порушують стійкість природних ландшафтів та екосистем, тому для зменшення негативного впливу стічних вод на довкілля та вирішення питання достатнього вологозабезпечення сільськогосподарських земель пропонуємо запроваджувати рециклінгові технології водокористування із залученням каналізаційно-зливових стічних вод для підґрунтового зрошення сільськогосподарських культур на міських та приміських землях, які підвищать екологічні, соціальні та економічні ефекти у веденні землеробства без зміни показників водовикористання під час вирощування сільськогосподарської продукції [9].

Стічні води, маючи меліоративну та удобрювальну цінність за рахунок вмісту у $1000 \mathrm{~m}^{3}$ каналізаційних стічних вод 15-88 кг азоту, 16-18 кг калію, 12-16 кг фосфору, 20-150 кг кальцію та магнію, сприяють збільшенню врожайності сільськогосподарських культур за лімітуючими елементами живлення, поліпшують якісні характеристики ґрунту та сільськогосподарської продукції, забезпечують отримання додаткового доходу під час вирощування озимої пшениці - 154,7 грн/га, ярої пшениці - 108,8 грн/га, кукурудзи на зерно - 186,5 грн/га, кукурудзи на корм - 816,3 грн/га, цукрових буряків 184,9 грн/га, соняшнику - 202,1 грн/га [10].

Під час дослідження можливостей здійснення зрошення такими водами визначено, що обсяг щорічного утворення поверхнево-каналізаційних міських стоків урбосистеми Херсону становить 20,5 млн м ${ }^{3}$.

Підготовлені для зрошення води доцільно використати для поливу земель поблизу населених пунктів.
Згідно з проведеною якісною оцінкою каналізаційних стоків на основі ДСТУ 2730 : 2015 [6], встановлено, що вода придатна для зрошення 3 умовою обов'язкового попереднього поліпшення (табл. 1).

Згідно з проведеною оцінкою придатності стічних вод за агрономічними критеріями для зрошування встановлено, що вода відноситься до другого класу придатності.

3 урахуванням даних Державного водного агентства України протягом останніх п'яти років зрошувані землі на території Херсонської області зрошувалися «обмежено придатною» та «непридатною» водою, що сприяло підвищеному рівню підлуження, засоленню ґрунтів, токсичному впливу зрошуваної води на рослини, погіршенню якості сільськогосподарської продукції. Тому під час використання міських каналізаційно-поверхневих стоків для зрошення сільськогосподарських культур необхідне здійснення доочистки на інженерних інфільтраційних спорудах біоплато (рис. 1). При цьому стічні води перед надходженням на поля зрошення треба пропускати через первинні відстійники у зв'язку з можливою присутністю у стічних водах яєць гельмінтів та патогенних мікроорганізмів. Ефективність такої біологічної доочистки становить $80 \%$, оскільки через дві години відстоювання затримується 90\% яєць гельмінтів.

Із метою уникнення аварійних ситуацій виникає потреба у будівництві аварійно-скидного ставка-накопичувача, який за незначних щоденних обсягів каналізаційних вод (50 тис м³) здатен увібрати й утримувати 5-7-денний стік міста. За цей час може бути ліквідована аварійна ситуація та відновлена робота міської очисної системи, після чого води ставка-накопичувача необхідно перенаправити на доочищення.

Пропонується також побудова локальних очисних споруд для здійснення механічної очистки з подальшим направленням поверхневих зливових вод на доочистку до міських очисних споруд, а потім - на біоплато. Домінування у стічній воді іонів $\mathrm{Na}^{+}$та $\mathrm{Cl}^{-}$свідчить про можливе осолонцювання та засолення ґрунтів, тому виникає необхідність їх гіпсування.

Окрім того, актуалізується питання підбору сівозміни 3 використанням ресурсозберігаючих режимів зрошення, що дасть змогу зменшити екологічне навантаження на ґрунт за рахунок відновлення запасів вологи у шарах ґрунту (табл. 2) [11].

Таблиця 1 - Оцінка придатності очищених стічних вод для зрошення

\begin{tabular}{|c|c|c|c|c|c|c|}
\hline \multirow{3}{*}{$\begin{array}{l}\text { Роки } \\
\text { сезон }\end{array}$} & \multicolumn{6}{|c|}{ Оцінка за показниками ДСТУ 2730 : 2015} \\
\hline & $\mathrm{Na}+\mathrm{K}$ & Mg & \multirow[t]{2}{*}{$\mathrm{Cl}$} & $\begin{array}{l}\text { загальна } \\
\text { лужність }\end{array}$ & $\begin{array}{l}\text { токсична } \\
\text { лужність }\end{array}$ & \multirow[t]{2}{*}{ Клас якості } \\
\hline & $\mathrm{Na}+\mathrm{K}+\mathrm{Ca}+\mathrm{Mg}$ & $\mathrm{Ca}$ & & $\mathrm{HCO}_{3}$ & $\mathrm{HCO}_{3}-\mathrm{Ca}$ & \\
\hline Травень 2019 & 60 & 0,07 & 10,66 & 1,94 & 3,91 & 2 \\
\hline Червень 2019 & 52 & 0,02 & 10,74 & 8,49 & 2,06 & 2 \\
\hline Липень 2019 & 55 & 0,05 & 10,60 & 7,36 & 1,59 & 2 \\
\hline серпень & 55 & 0,03 & 8,18 & 12,11 & 1,86 & 2 \\
\hline $\bar{x}$ & 55 & 0,04 & 10,04 & 7,47 & 1,43 & 2 \\
\hline Червень 2020 & 69 & 0,05 & 9,17 & 9,73 & 2,98 & 2 \\
\hline Липень 2020 & 77 & 0,13 & 10,00 & 6,61 & 2,16 & 2 \\
\hline Серпень 2020 & 74 & 0,04 & 9,84 & 7,87 & 2,07 & 2 \\
\hline $\bar{x}$ & 73 & 0,07 & 7,67 & 8,07 & 2,40 & 2 \\
\hline
\end{tabular}




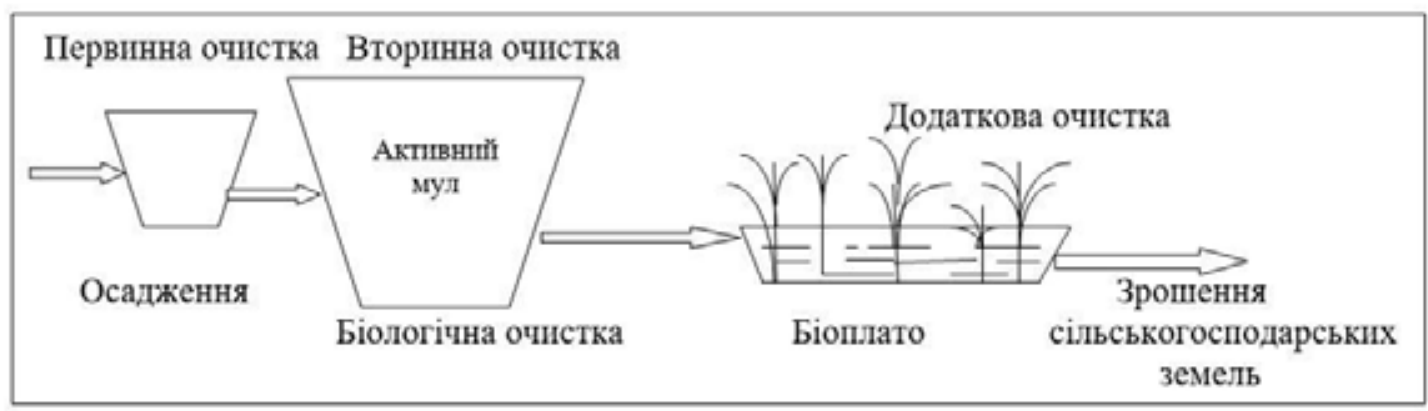

Рис. 1. Приклад біоплато для доочистки поверхнево-каналізаційних стічних вод

Таблиця 2 - Зерново-кормова сівозміна сільськогосподарських культур

\begin{tabular}{|c|l|c|}
\hline \multirow{2}{*}{ № } & $\begin{array}{c}\text { Чергування сільсько- } \\
\text { господарських культур }\end{array}$ & $\begin{array}{c}\text { 3рошувальна } \\
\text { норма м³/га }\end{array}$ \\
\hline 1 & Люцерна & 3000 \\
\hline 2 & Люцерна & 2700 \\
\hline \multirow{2}{*}{3} & Озима пшениця & 1050 \\
\cline { 2 - 3 } & Злаково-бобова суміш & 1150 \\
\hline 4 & Кукурудза на зерно & 1250 \\
\hline 5 & Кукурудза на зерно & 1250 \\
\hline 6 & Підсів люцерни & 900 \\
\hline
\end{tabular}

Середньозважена зрошувальна норма нетто становить 2079 м³/га, ураховуючи коефріцієнт корисної дії закритої зрошуваної системи ( $\eta=0,96$, норма брутто

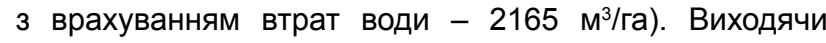
з установленого обсягу каналізаційних вод (18 млн м³ на рік), зрошення можна здійснити на 8314 га. 3 урахуванням додаткового поверхневого зливового стоку обсягом 2,5 млн м³ на рік площа зрошувальних земель може бути збільшена до 9468 га.

Використання ресурсозберігаючих режимів зрошення сільськогосподарських культур із застосуванням очищених поверхнево-каналізаційних вод згідно з вимогами якості поливної води є одним із методів оптимізації поливу. Він $€$ доцільним в умовах дефіциту водних ресурсів та недостатнього природного зволоження земель досліджуваної території, сприяє ефективному поповненню поживних речовин, продуктивних запасів вологи у ґрунтах, зменшенню техногенного навантаження на ґрунт, отриманню якісної сільськогосподарської продукції [51].

Висновки. Згідно з проведеними дослідженнями встановлено, що глобальні зміни клімату призвели до десріциту природного вологозабезпечення сільськогосподарських земель Херсонської області, унаслідок чого зволоження стало лімітуючим екологічним чинником визначення продуктивності сільськогосподарських культур. Для вирішення проблеми поповнення вологою ґрунтів в умовах низької водозабезпеченості досліджуваної території запропоновано використання очищених до нормативних вимог поверхнево-каналізаційних стічних вод. Обґрунтовано необхідність побудови аварійно-скидного ставка-накопичувача, локальних очисних споруд для механічної очистки поверхневих вод та інженерно-біологічної споруди типу біоплато для доочистки стічних вод відповідно до вимог якості зрошуваної води.
Доведено, що повторне використання каналізаційно-поверхневих стоків забезпечить зрошення міських та приміських земель для вирощування сільськогосподарських культур на площі 9468 га.

\section{СПИСОК ВИКОРИСТАНОÏ ЛІТЕРАТУРИ:}

1. Національна доповідь про стан навколишнього природного середовища в Україні у 2018 році. Київ, 2019. 483 c.

2. Калетнік Г.М., Гончарук Т.В. Перспективи використання стічних каналізаційних вод м. Вінниці для підживлення польових культур: вітчизняний та зарубіжний досвід. Збалансоване природокористування. 2016. № 3. C. 42-47. URL: http://nbuv.gov.ua/UJRN/ Zp_2016_3_8.

3. Salakinkop S.R., Hunshal C.S. Domestic sewage irrigation on dynamics of nutrients and heavymetals in soil and wheat (Triticum aestivumL.) production. Int $J$ Recycl Org Waste Agricult. 2014. Vol. 3(64). P. 1-11.

4. Еколого-економічний ефект реклеймінгу стічних вод на підприємствах України / О.М. Маценко та ін. Агросвіт. 2019. № 16. С. 58-66.

5. Городній М.М. Проблеми використання осадів стічних вод для виробництва добрив. Вісник аграрної науки. 2013. № 9. С. 45-50.

6. ДСТУ 2730:2015. Захист довкілля. Якість природної води для зрошення. Агрономічні критерії [Чинний від 2016-07-01]. Вид. офріц. Київ : УкрНДНЦ, 2016. 9 с.

7. Литовченко О.Ф. Новий ресурсозберігаючий метод розрахунку режимів зрошення сільськогосподарських культур у степовій і лісостеповій зонах України. Таврійський науковий вісник. 2005. Вип. 41. С. 83-93.

8. Method of forecasting the agro-ecological state of soils on the example of the south of Ukraine20th / D.S. Breus et al. International Multidisciplinary Scientific GeoConference SGEM 2020. Vol. 20. Book 5.1. P. 523-528. DOI: $10.5593 /$ sgem2020/5.1/s20.066.

9. Causal regularities of effect of urban systems on condition of hydro ecosystem of Dnieper river / V. Pichura et al. Indian Journal of Ecology. 2020. № 47(2). P. 273-280.

10. Хоружий П., Чорнокозинський А., Хоружий В. Доочистка стічних вод для підгрунтового зрошення на біофільтрах з плаваючим завантаженням. Водне господарство України. 2000. № 1-2. С. 25-26.

11. Skok S.V. The research of possibility of using sewage of urbosystem in forage crop rotation for organic livestock farming. Geo-management in organic agriculture : monografia viacerých autorov. Podhájska, 2019. P. 226-235. 


\section{REFERENCES:}

1. Natsionalna dopovid pro stan navkolyshnioho pryrodnoho seredovyshcha v Ukraini u 2018 rotsi [National report on the state of the environment in Ukraine in 2018]. (2019). Kyiv: Ministerstvo ekolohii ta pryrodnykh resursiv Ukrainy [in Ukrainian].

2. Kaletnik H.M., Honcharuk T.V. (2016). Perspektyvy vykorystannia stichnykh kanalizatsiinykh vod m. Vinnytsi dlia pidzhyvlennia polovykh kultur: vitchyznianyi ta zarubizhnyi dosvid [Prospects for the use of sewage in Vinnytsia for fertilization of field crops: domestic and foreign experience]. Zbalansovane pryrodokorystuvannia - Balanced use of nature, 3 , 42-47. URL: http://nbuv.gov.ua/UJRN/Zp_2016_3_8 [in Ukrainian]

3. Salakinkop S.R., Hunshal C.S. (2014). Domestic sewage irrigation on dynamics of nutrients and heavymetals in soil and wheat (Triticum aestivumL.) production. Int $J$ Recycl Org Waste Agricult, 3 (64), 1-11 [in English].

4. Ekoloho-ekonomichnyi efekt rekleiminhu stichnykh vod na pidpryiemstvakh Ukrainy [Ecological and economic effect of wastewater reclamation at the enterprises of Ukraine] / Matsenko O.M. ta inshi. (2019). AhrosvitAgroworld, 16, 58-66 [in Ukrainian].

5. Horodnii M.M. (2013). Problemy vykorystannia osadiv stichnykh vod dlia vyrobnytstva dobryv [Problems of using sewage sludge for fertilizer production]. Visnyk ahrarnoi nauky-Bulletin of Agricultural Science, 9, 45-50 [in Ukrainian]

6. DSTU 2730:2015 (2016). Zakhyst dovkillia. Yakist pryrodnoi vody dlia zroshennia. Ahronomichni kryterii [Environmental Protection. Quality of natural water for irrigation. Agronomic criteria]. [Chynnyi vid 2016-07-01]. Vyd. ofits. Kyiv: UkrNDNTs, 9 [in Ukrainian].

7. Lytovchenko O.F. (2005). Novyi resursozberihaiuchyi metod rozrakhunku rezhymiv zroshennia silskohospodarskykh kultur u stepovii i lisostepovii zonakh Ukrainy [A new resource-saving method for calculating irrigation regimes of agricultural crops in the steppe and forest-steppe zones of Ukraine]. Tavriiskyi naukovyi visnyk- Taurian Scientific Bulletin, 41, 83-93 [in Ukrainian].

8. Breus D.S., Evtusenko O.V., Skok S.V., Rutta O.V. (2020). Method of forecasting the agro-ecological state of soils on the example of the south of Ukraine. 20th International Multidisciplinary Scientific GeoConference SGEM, 20, 5.1, 523-528 DOI: 10.5593/sgem2020/5.1/ s20.066

9. Pichura V., Potravka L., Skok S., Vdovenko N. (2020). Causal regularities of effect of urban systems on condition of hydro ecosystem of Dnieper river. Indian Journal of Ecology, 47(2), 273-280.

10. Khoruzhyi P., Chornokozynskyi A., Khoruzhyi V. (2000). Doochystka stichnykh vod dlia pidhruntovoho zroshennia na biofiltrakh $\mathrm{z}$ plavaiuchym zavantazhenniam [Additional wastewater treatment for groundwater irrigation on floating biofilters]. Vodne hospodarstvo Ukrainy-Water management of Ukraine, 1-2, 25-26 [in Ukrainian].

11. Skok S.V. (2019). The research of possibility of using sewage of urbosystem in forage crop rotation for organic livestock farming. Geo-management in organic agriculture. Monografia viacerých autorov. Podhájska, 226-235.
Скок С.В. Оцінка придатності стічних вод для зрошення сільськогосподарських культур

Мета. Здійснити оцінку придатності стічних вод для зрошення сільськогосподарських культур за агрономічними критеріями. Методи. Придатність каналізаційно-поверхневих стоків за агрономічними критеріями для зрошення сільськогосподарських культур встановлена відповідно до ДСТУ 2730:2015 «Захист довкілля. Якість природної води для зрошення. Агрономічні критерії», можливість розширення площ зрошення розраховано за методикою розрахунку ресурсозберігаючих режимів зрошення сільськогосподарських культур. Оцінка придатності стічних вод для зрошення включала рівень небезпеки розвитку деструктивних процесів на зрошуваних ґрунтах за показниками засолення ґрунтів, за сумою токсичних солей; залуження ґрунтів за загальною та токсичною лужністю; осолонцювання ґрунтів за відношенням вмісту лужних катіонів натрію і калію до суми усіх катіонів. Результати. Згідно з проведеними дослідженнями встановлено, що несприятливі кліматичні умови, які проявляються у недостатньому природному вологозабезпеченні на території Херсонської області для ведення сільського господарства, вимагають пошуку альтернативних джерел зрошення сільськогосподарських культур, тому для підвищення продуктивності рослинництва та покращення ефективності використання земельно-ресурсного потенціалу запропоновано застосування рециклінгових технологій водокористування із залученням каналізаційно-зливових стічних вод для підґрунтового зрошення сільськогосподарських культур на міських та приміських землях. Згідно з проведеною оцінкою придатності стічних вод за агрономічними критеріями для зрошування запропонованої зерново-кормової сівозміни встановлено, що вода відноситься до другого класу придатності, може бути використана для зрошення сільськогосподарських земель з умовою обов'язкового попереднього поліпшення. Як доочистку стічних вод запропоновано спорудження інженерно-біологічної споруди типу біоплато. За обсягом щорічного утворення поверхнево-каналізаційних міських стоків урбосистеми Херсон об'ємом 20,5 млн м³ площа зрошувальних земель може сягати до 9468 га. Висновки. Ефективним заходом раціонального використання водних ресурсів, вирішення проблеми дефіциту природного вологозабезпечення, підвищення ефективності ведення сільського господарства в умовах посушливого клімату запропоновано впровадження оптимізованої сівозміни, застосування ресурсозберігаючих режимів зрошення сільськогосподарських культур із застосуванням очищених поверхнево-каналізаційних вод відповідно до агрономічних вимог якості поливної води.

Ключові слова: альтернативне джерело водокористування, дефіцит водних ресурсів, вологозабезпечення, зрошувальна норма, сівозміна, ресурсозберігаючі методи поливу.

Skok S.V. Evaluation of the suitability of wastewater for crop irrigation

Purpose. To evaluate the suitability of wastewater for crop irrigation by agronomic criteria. Methods. The suitability of surface sewage effluents for crop irrigation by agronomic criteria was established according to the State Standard 2730:2015 "Environmental protection. Quality of natural water for irrigation. Agronomic criteria". The possibility of enlarging irrigation areas was determined 
by the method of calculating resource-saving regimes for crop irrigation. Evaluation of the suitability of wastewater for irrigation considered the threat level of the development of destructive processes on irrigated soils, by the indexes of soil salinity by the sum of toxic salts; soil alkalization by general and toxic alkalinity; soil salinization by the ratio of the content of alkaline sodium and potassium cations and the sum of all the cations. Research results. The research made it possible to establish that unfavorable weather conditions manifesting themselves in the lack of natural moisture supply in the territory of Kherson region for farming require searching for alternative sources for crop irrigation. Therefore, in order to increase productivity of crop production and improve efficiency of using the potential of land resources we suggest applying recucling technologies of water use using sewage effluents and and stormwater for crop sub-irrigation on urban and suburban lands. According to our evaluation of the suitability of wastewater by agronomic criteria for irrigating the suggested grain and fodder crop rotation, we established that the water is referred to the second class of suitability and can be used for crop irrigation provided that it is to be improved prior to use. We recommend construction of an engineering-biological structure of a bioplateau type for additional treatment of wastewater. The area of irrigated lands can reach 9468 ha by the amount of annual urban surface sewage effluents of the urbosystem Kherson with the capacity of 20.5 million $\mathrm{m}^{3}$. Conclusions. We suggest applying optimized crop rotation and resourcesaving regimes for crop irrigation with using treated surface sewage effluents according to agronomic requirements for the quality of irrigation water as an efficient measure for efficient use of water resources, for solving the problem of scarcity of natural moisture supply and increasing agricultural efficiency under conditions of dry climate.

Key words: alternative source of water use, scarcity of water resources, moisture supply, irrigation norm, crop rotation, resource-saving irrigation methods. 